\title{
Cattle Grazing Blue Grama Rangeland I. Seasonal Diets and Rumen Fermentation
}

\author{
F.T. MCCOLLUM, M.L. GALYEAN, L.J. KRYSL, AND J.D. WALLACE
}

\section{Abstract}

Four field trials were conducted from early August to late October, 1982, on blue grama (Boutelowa gracilis) rangeland in south-central New Mexico to examine relationships among grazing season, diet botanical and chemical composition, and rumen fermentation in beef steers (Bos taurus). Diets contained an average of $83 \%$ grasses and $17 \%$ forbs from early August through late September and $77 \%$ forbs in late October. Cell wall content of the diet decreased from the early growing season (74.9\%) through the onset of dormancy (64.9\%) while acid detergent fiber and lignin increased (41.9 to $52.9 \%$ and 5.2 to $12.7 \%$, respectively) and crude protein content declined from 18.4 to $11.7 \%$. Soluble and insoluble nitrogen ( $N$ ) fractions of the diet reflected crude protein; from 13 to $36 \%$ of $\mathrm{N}$ was in unavailable forms. The extent of in vitro organic matter digestion declined from the early growing season (66.5\%) through onset of dormancy (47.9\%). Ruminal ammonia concentrations declined as season progressed: $6.0 \mathrm{mg} / 100 \mathrm{ml}$ was the lowest concentration observed. Declining diet quality was accompanied by an upward shift in digesta $\mathrm{pH}$ and altered proportions of volatile fatty acids (VFA) in rumen contents. Total VFA concentration was highest in late August (106.3 mmoles/liter). Ruminal measures generally reflected changes in dietary protein and digestibility but concentrations could also reflect changes in digesta flow rates. Finally, data suggest that crude protein may not be a good measure of protein supply to livestock grazing on ranges with diverse forage types.

Several authors have discussed the influence of advancing season of growth and nutritive value of range plants and relative values of forage classes (Cook 1983, Pieper et al. 1978, Kothmann 1980). Such changes are usually discussed in relation to the daily requirements of animals grazing in the plant communities. However, few studies have related diet quality to ruminal environment in the grazer. The rumen is the primary site of forage degradation. Products of ruminal fermentation (ammonia, volatile fatty acids) and the pH of ruminal contents can influence fiber digestion (Mertens 1979), microbial protein synthesis (Satter and Slyter 1974), and, finally, energy and protein supplied to the grazing host. Therefore, knowledge of seasonal fermentation patterns in grazing range animals might suggest means of enhancing diet utilization and animal performance.

The objectives of this study and another reported subsequently (McCollum and Galyean 1985) were to relate seasonal changes in diet composition with changes in rumen function and forage intake in beef steers (Bos taurus) grazing native blue grama (Bouteloua gracilis) rangeland during 4 periods of a growing season.

\section{Materials and Methods}

\section{Study Area}

The Fort Stanton Experimental Ranch is in the foothills between the Sierra Blanca and Capitan Mountains in southern Lincoln County, New Mexico. Pieper et al. (1971) described the vegetation, topography, and climate of the Ft. Stanton Ranch. Briefly, annual precipitation averages $40 \mathrm{~cm}$ and mean annual

\footnotetext{
At the time of this research, authors were graduate assistant, associate professor, graduate assistant, and professor, respectively, Department of Animal and Range Sciences, New Mexico State University, Las Cruces $\mathbf{8 8 0 0 3}$. McCollum is currently assistant professor, Animal Science Department, Oklahoma State University, Stillwater 74078 .

This article is a contribution from New Mexico Agr. Exp. Sta. Juurnal Article No. 1087.

The authors wish to acknowledge the assistance of Drs. A.L. Goetsch, R.E. Estell, and M.B. Judkins, E.E. Parker, and Harley Segotta.

Manuscript accepted 19 April 1985.
}

temperature is $11.1^{\circ} \mathrm{C}$. Most vegetational growth usually occurs during June through September. The study pasture, an open grassland area, was situated at approximately 1,900 m elevation and received about $35 \mathrm{~cm}$ precipitation the year of the study $(65 \%$ occurred between mid-July and the end of September). Vegetation of the study pasture was dominated by blue grama and cholla cactus (Opuntia imbricata) (Pieper et al. 1971).

\section{Field trials}

Four trials were conducted during 1982 (9 Aug.-17 Aug., EAug; 29 Aug.-Aug.-4 Sept., LAug; 23 Sept.-1 Oct., LSept; 23 Oct.-31 Oct., LOct). Trials were conducted at these times to reflect phenological changes in the plant community. During each trial, 3 esophageal-cannulated dry, mature beef cows (Hereford $X$ Angus) and 6 rumen-cannulated $(10.2 \mathrm{~cm}$ ID cannulas) steers (Hereford $X$ Angus; $\bar{x}$ weight $=303 \mathrm{~kg}$ ) were allowed to freely graze the pasture. No other animals were grazed on the study pasture during adjustment and sampling periods. It was assumed that the diets of the cows and steers were similar. Cows were placed on pasture a minimum of 1 week before each trial, while steers were placed on pasture 2 weeks before the EAug trial and grazed continuously through the LOct sampling period.

Diet samples were collected the first 2 days of each 8 -day trial. The cows were penned each day at 1200 hour and samples were collected during 30-minute periods between 1700 and 1800 hours. The cows were hazed to the area being grazed by the steers during collection periods. Following the collections, an aliquot of each extrusa sample was frozen in a plastic bag and stored until analyzed.

Rumen samples were collected on the third day of each trial. At 0800 hours, $250-\mathrm{ml}$ sample of whole rumen contents was withdrawn after thorough hand-mixing of the rumen. Rumen $\mathbf{p H}$ was evaluated immediately with a combination electrode. Samples were strained through 4 layers of cheesecloth, and strained fluid was acidifed ( $1 \mathrm{ml} 20 \% \mathrm{v} / \mathrm{v} \mathrm{H}_{2} \mathrm{SO}_{4}$ per $100 \mathrm{ml}$ strained fluid) and stored frozen. After sampling, steers were allowed to return to normal grazing activities. The sampling process was then repeated at 1200,1600 , and 2000 hours. To facilitate rumen sampling, temporary pens were transported to and erected on an area immediately adjacent to the site being grazed by the steers at each sampling time.

\section{Laboratory Analyses}

Esophageal samples were dried at $50^{\circ} \mathrm{C}$ for 54 hours and ground through a $2-\mathrm{mm}$ screen in a Wiley mill. Dry matter and ash contents were determined by standard procedures (AOAC 1980). Dietary fiber constituents (acid detergent fiber, ADF; acid detergent lignin, ADL; neutral detergent fiber or cell walls, NDF) were determined according to Goering and Van Soest (1970). Nitrogen (N) was determined by Kjeldahl procedures (AOAC 1980) and fractioned into soluble $\mathrm{N}$ (SN) and insoluble $\mathrm{N}$ (IN) by the sodium chloride method of Waldo and Goering (1979). Insoluble unavailable $\mathbf{N}$ (ADIN) was the $\mathrm{N}$ present in ADF residue. Crude protein (CP) was calculated as $6.25 \times \mathrm{N}$.

In vitro digestion analyses were conducted on samples composited across cows and sampling days. Rumen fluid inoculum was collected from 3 steers consuming a 50:50 mixture of alfalfa ( $M$ edicago sativa) and prairie hay. Extent of organic matter disappearance (IVOMD) was estimated using techniques of Tilley and Terry (1963). 
Microhistological examination of dried and ground esophageal masticate samples followed procedures outlined by Sparks and Malechek (1968). Ten systematically located fields per slide and 5 slides per sample (individual cow samples) were examined at $100 \mathrm{X}$ magnification.

Rumen samples were thawed overnight at room temperature, after which $40 \mathrm{ml}$ of fluid was drawn from each sample and centrifuged at $12,000 \times \mathrm{g}$ for 10 minutes. The supernatant fraction was decanted and a portion analyzed for ammonia $\left(\mathrm{NH}_{3}-\mathrm{N}\right)$ by the phenol-hypochlorite procedure of Broderick and Kang (1980). Five milliliters of the remaining portion of supernatant fluid was mixed with $1 \mathrm{ml}$ of $25 \%(\mathrm{w} / \mathrm{v})$ metaphosphoric acid containing approximately $2 \mathrm{~g}$ 2-ethylbutyric acid (internal standard) per liter and recentrifuged at $12,000 \times \mathrm{g}$ for 10 minutes. The resulting supernatant fraction was analyzed for volatile fatty acids (VFA) as described by Goetsch and Galyean (1983).

\section{Statistical Analyses}

Analysis of variance of diet data was conducted assuming a completely randomized design with effects for season considered in the model. Rumen fermentation data were analyzed by analysis of variance with effects for season, time of day, and season $X$ time of day. Variables with a significant $(P<.05)$ season $X$ time of day interaction were reanalyzed within time of day and season. Means were separated using the least significant difference method protected by a significant $F$ test.

\section{Results and Discussion}

\section{Botanical Composition of Diets}

Diets collected via esophageal fistula contained an average of $83 \%$ grasses and $17 \%$ forbs in EAug, LAug and LSept (Table 1). In

Table 1. Grass and forb content of cattle diets grazed from blue grama rangeland during different sampling periods. 1

\begin{tabular}{lcc}
\hline \hline Sampling period & Grasses & Forbs \\
\hline & $85.7 \mathrm{a}^{3}$ & $14.3 \mathrm{a}$ \\
EAug & $83.2 \mathrm{a}$ & $16.8 \mathrm{a}$ \\
LAug & $81.3 \mathrm{a}$ & $18.7 \mathrm{a}$ \\
LSept & $22.7 \mathrm{~b}$ & $77.3 \mathrm{~b}$ \\
LOct & 2.7 & 2.7 \\
SE $^{2}$ & & \\
\hline
\end{tabular}

1Primary grasses and forbs in the diets were: Bouteloua gracilis, Muhlenbergia richardsonii, Lycurus phleoides, Sporobulus cryptandrus, Spharalcea angustifolia and Artemisia carruthii.

2Standard error of treatment means, $n=3$.

${ }^{3}$ Column means followed by different letters are different $(P<.05)$.

contrast, forbs accounted for $77 \%$ of the LOct diet. Blue grama and mat muhly (Muhlenbergia richardsonii) were the primary grasses consumed during the study. The major forbs utilized by the experimental animals were Carruth sagewort and scarlet globemallow (Artemisia carruthi' and Spharalcea coccinea, respectively).

Havstad (1977) and Pfister et al. (1984) also reported shifts in floral composition of cattle diets at $\mathrm{Ft}$. Stanton. However, the greatest contribution of forbs in these studies was $47 \%$. The shifts observed in the current study demonstrate the value of forbs during periods when nutritive quality of warm-season grasses is declining. The LOct sampling date was about 2 weeks after the first fall frost. Hence, grasses were in early dormancy and were probably less palatable than forbs which mature less rapidly and maintain palatability for a longer period of time during the dormant season (Cook 1983).

\section{Diet Quality}

Dietary NDF declined as time progressed from EAug to the onset of dormancy (LOct) for the warm-season grasses (Table 2). Normally, advancing maturity is associated with increased cell wall constituents (Van Soest 1982). However, the declining NDF and
Table 2. Organic matter, fiber contents, and extent of organic matter disappearance from diets of cattle graxing blue grama rangeland during different sampling periods.

\begin{tabular}{lccccc}
\hline \hline & \multicolumn{4}{c}{ Sampling period } & \\
\cline { 2 - 5 } Item & EAug & LAug & LSept & LOct & SE $^{\prime}$ \\
\hline & & & $-\%$ & & \\
Organic matter & 83.4 & 81.8 & 85.4 & 83.3 & 1.1 \\
Neutral detergent fiber $^{3}$ & $74.9 \mathrm{a}^{2}$ & $75.8 \mathrm{a}$ & $\mathbf{6 9 . 9 \mathrm { b }}$ & $64.9 \mathrm{c}$ & 1.4 \\
Acid detergent fiber $^{3}$ & $41.9 \mathrm{a}$ & $\mathbf{4 6 . 8 \mathrm { b }}$ & $\mathbf{4 8 . 3 \mathrm { bc }}$ & $52.9 \mathrm{c}$ & 1.4 \\
Acid detergent lignin $^{3}$ & $5.2 \mathrm{a}$ & $6.5 \mathrm{a}$ & $9.0 \mathrm{~b}$ & $12.7 \mathrm{c}$ & 0.7 \\
In vitro digestibility $^{3}$ & $66.5 \mathrm{a}$ & $\mathbf{6 3 . 1 \mathrm { a }}$ & $51.6 \mathrm{~b}$ & $\mathbf{4 7 . 9 \mathrm { b }}$ & 2.5 \\
\hline
\end{tabular}

iStandard error of treatment means, $n=3$.

${ }_{2}$ Means in a row followed by different letters differ $(P<.05)$.

${ }^{3}$ Organic matter basis.

increasing ADL contents are indicative of the increasing forb component in diets from EAug to LOct. These plant materials usually contain less cell wall and more lignin than grasses (Kothmann 1980, Cook 1983, Van Soest 1982).

Acid detergent fiber content of the diets rose from $41.9 \%$ in EAug to $52.9 \%$ in LOct (Table 2). Similar trends and values were reported in other diet (Cordova 1978; Havstad 1977) and clipping studies (Pieper et al. 1978) at Ft. Stanton. As season advanced from EAug to LAug, changes in dietary ADF were primarily due to cellulose levels. But, from LAug to LSept and LOct, alterations in dietary ADF were accounted for by increasing amounts of ADL (Table 2) contributed by the maturing grass and lignified forb components of the diets.

As season advanced and the lignocellulose fractions of the diets increased, the extent of IVOMD declined $(P<.05)$ from $66.5 \%$ in EAug to $47.9 \%$ in LOct (Table 2). Cordova (1978) and Havstad (1977) reported similar seasonal patterns. After 4 hours incubation, LOct diets were digested to a greater extent $(P<.05)$ than diets from other months (McCollum and Galyean 1985). However, this advantage disappeared as incubation time increased and, utimately, LOct diets were not as digestible as diets from EAug and LAug. The early, rapid disappearance of the LOct diets is typical of nongrass plant species. Forb and shrub leaves have much more rapid rates of digestion than grasses (Short et al. 1974, Kothmann 1980). Although there were no statistical differences, comparison of LSept and LOct data demonstrate that increased forb consumption was accompanied by a faster rate (McCollum and Galyean 1985), but lesser extent, of IVOMD. Early season diets were digested to a greater extent and at a faster rate than late season diets.

In all months, dietary CP (Table 3) was adequate for growing heifers and steers (minimum wt. $225 \mathrm{~kg}$ ) gaining $.5 \mathrm{~kg}$ per day (9.5-10\%), pregnant cows (7-8\%), and yearling heifers (8-9\%), and lacating cows $(9-10 \%)$ and heifers $(9-11 \%$; NRC, 1984). These

\section{Table 3. Crude protein and nitrogen fractions of esophageal diet samples from cattle grazing blue grama rangeland during different sampling periods.}

\begin{tabular}{lcccccc}
\hline \hline & \multicolumn{5}{c}{ Sampling period } & \\
\cline { 2 - 5 } Item $^{2}$ & EAug & LAug & LSept & LOct & SEI \\
\hline & $18.4 \mathrm{a}^{3}$ & $17.6 \mathrm{a}$ & $12.7 \mathrm{~b}$ & $11.7 \mathrm{~b}$ & 0.8 \\
Crude protein & $2.94 \mathrm{a}$ & $2.82 \mathrm{a}$ & $2.03 \mathrm{~b}$ & $1.87 \mathrm{~b}$ & 0.1 \\
Total nitrogen & $0.88 \mathrm{a}$ & $0.78 \mathrm{a}$ & $0.58 \mathrm{~b}$ & $0.48 \mathrm{~b}$ & 0.04 \\
Soluble nitrogen & $2.07 \mathrm{a}$ & $2.03 \mathrm{a}$ & $1.44 \mathrm{~b}$ & $1.39 \mathrm{~b}$ & 0.11 \\
Insoluble nitrogen & $1.68 \mathrm{a}$ & $1.63 \mathrm{a}$ & $0.96 \mathrm{~b}$ & $0.72 \mathrm{c}$ & 0.07 \\
Insoluble available nitrogen & & & & & \\
$\begin{array}{l}\text { Acid detergent insoluble } \\
\quad \text { nitrogen }\end{array}$ & $0.39 \mathrm{a}$ & $0.41 \mathrm{a}$ & $0.48 \mathrm{a}$ & $0.67 \mathrm{~b}$ & 0.05 \\
\hline
\end{tabular}

iStandard error of treatment means, $\mathrm{n}=3$.

2Organic matter basis.

${ }^{3}$ Means in a row followed by different letters differ $(P<.05)$. 
requirements assume daily dry matter intake is adequate. Diets collected during August contained in excess of $17 \%$ CP. After declining $(P<.05)$ to $12.7 \%$ in $\mathrm{LSept}$, dietary $\mathrm{CP}$ remained relatively unchanged as season progressed to LOct. The absence of any great reduction in dietary $\mathrm{CP}$ as plants matured and moved into early dormancy can be attributed to increased forb consumption. As plants mature, CP levels decline; however, forbs generally maintain a higher concentration of CP than grasses (Cook 1983). Although seasonal trends noted in this study agree with earlier Ft. Stanton trials (Cordova 1978, Havstad 1977), CP levels are higher than in those other studies.

Seasonal course and variation of $S N$ and IN contents (\% of OM) reflected CP values (Table 3). Expressed as a percentage of total dietary $\mathrm{N}, 29,28,29$, and $26 \%$ of dietary $\mathrm{N}$ was in the soluble fraction during EAug, LAug, LSept, and LOct, respectively. Kempton et al. (1977) suggested that $\mathbf{N}$ solubility decreases with plant maturity. In contrast, there was no apparent decline in dietary $\mathbf{N}$ solubility as season progressed. Soluble $\mathbf{N}$ is an important $\mathbf{N}$ source for ruminal microbial activities, but the IN fraction may be of greatest importance because of its substantial contribution to total $\mathbf{N}$ and partial unavailability. The IN fraction is composed of available and relatively unavailable (ADIN) $\mathrm{N}$ components. Thirteen, 14,24 , and $36 \%$ of dietary CP was bound in the ADIN fraction during EAug, LAug, LSept, and LOct, respectively. Thus, available protein in the diets was lower than indicated by $\mathrm{CP}$ estimates. Estimates of available CP were $16.0,15.0,9.7$, and $7.5 \%$ from EAug through LOct. The large differences between total CP and available CP observed in both LSept and LOct is possibly accounted for by the lignin content of the diets (Table 2). Phenolic monomers present in the lignin and other plant constituents are capable of binding $N$, thereby limiting availability to the animal (Jung and Fahey 1983). These results suggest CP, measured as total $\mathrm{N} \times 6.25$, may not be the best measure to determine $\mathrm{N}$ needs of ruminants grazing in plant communities with diverse forage types.

\section{Rumen Fermentation Measurements}

Season $\times$ time of day interactions $(P<.05)$ were observed for rumen $\mathrm{NH}_{3}-\mathrm{N}$ (Table 4) and rumen pH (Table 5). Therefore, the

Table 4. Rumen ammonia-N concentrations at various times of the day in beef steers grazing blue grama rangeland during different sampling periods.

\begin{tabular}{|c|c|c|c|c|c|}
\hline \multirow[b]{2}{*}{ Item } & \multicolumn{4}{|c|}{ Sampling period } & \multirow[b]{2}{*}{$\mathbf{S E}^{1}$} \\
\hline & EAug & LAug & LSept & LOct & \\
\hline Time of day, hours & & $--m g$ & $100 \mathrm{ml}-$ & & \\
\hline $\begin{array}{l}0800 \\
1200 \\
1600 \\
2000\end{array}$ & $\begin{array}{l}17.6 \mathrm{a}^{2} \\
17.8 \mathrm{a} \\
18.4 \mathrm{a} \\
24.2 \mathrm{a}\end{array}$ & $\begin{array}{l}22.1 b \\
27.2 b \\
23.7 b \\
24.7 a\end{array}$ & $\begin{array}{r}11.8 \mathrm{c} \\
8.4 \mathrm{c} \\
13.1 \mathrm{c} \\
15.2 \mathrm{~b}\end{array}$ & $\begin{array}{l}7.5 \mathrm{~d} \\
7.2 \mathrm{c} \\
6.7 \mathrm{~d} \\
6.0 \mathrm{c}\end{array}$ & $\begin{array}{l}1.4 \\
1.1 \\
1.1 \\
1.1\end{array}$ \\
\hline
\end{tabular}

iStandard error of treatment means, $n=6$.

${ }_{2}^{2}$ Means in a row followed by a different letter differ $(P<.05)$.

data were analyzed for effects of season within time of day. Generally $\mathrm{NH}_{3}-\mathrm{N}$ concentrations were consistent across time of day, indicating fairly static input to and utilization of the ruminal $\mathrm{NH}_{3}-\mathrm{N}$ pool. Seasonally, lowest $\mathrm{NH}_{3}-\mathbf{N}$ concentrations coincided with late growing and early dormant seasons (LSept and LOct, respectively) and low concentrations of dietary $N$. Although dietary $\mathbf{N}$ concentration was lower in LAug than EAug, steers maintained higher $(P<.05$ at 0800,1200 , and 1600 hours $) \mathrm{NH}_{3}-\mathrm{N}$ levels in LAug. This difference may have been the result of reduced rumen fluid passage rate (McCollum and Galyean 1985) and reduced $\mathrm{NH}_{3}-\mathrm{N}$ flow from the rumen during LAug, compared with EAug.

Other workers have observed twofold increases in rumen $\mathrm{NH}_{3}-\mathrm{N}$ concentrations during wet vs dry seasons of the year (Playne and
Table 5. Rumen pH at various times of the day in beef steers grazing blue grama rangeland during different sampling periods.

\begin{tabular}{llllll}
\hline \hline & \multicolumn{5}{c}{ Sampling period } \\
\cline { 2 - 5 } Item & EAug & LAug & LSept & LOct & SE $^{\prime}$ \\
\hline Time of day, hours & & & & & \\
0800 & $6.2 \mathrm{a}^{2}$ & $6.4 \mathrm{~b}$ & $6.4 \mathrm{~b}$ & $6.7 \mathrm{c}$ & 0.05 \\
1200 & $6.2 \mathrm{a}$ & $6.5 \mathrm{~b}$ & $6.1 \mathrm{a}$ & $6.6 \mathrm{~b}$ & 0.06 \\
1600 & $6.2 \mathrm{a}$ & $6.5 \mathrm{~b}$ & $6.2 \mathrm{a}$ & $6.5 \mathrm{~b}$ & 0.07 \\
2000 & $6.1 \mathrm{a}$ & $6.1 \mathrm{ab}$ & $6.3 \mathrm{bc}$ & $6.4 \mathrm{c}$ & 0.07 \\
\hline
\end{tabular}

'Standard error of treatment means, $n=6$.

2 Means in a row followed by different letters differ $(P<.05)$.

Kennedy 1976). This change was attributed to higher dietary $\mathrm{N}$ levels. In the present study, rumen $\mathrm{NH}_{3}-\mathrm{N}$, averaged for the growing season sampling periods (EAug, LAug, LSept), was threefold greater $(18.7 \mathrm{mg} / 100 \mathrm{ml})$ than the average value for the early dormant season sampling period $(6.3 \mathrm{mg} / 100 \mathrm{ml})$. Despite no difference $(P>.05)$ in dietary CP between LSept and LOct, ruminal $\mathrm{NH}_{3}-\mathrm{N}$ concentrations were 1.2 to $9.1 \mathrm{mg} / 100 \mathrm{ml}$ greater in LSept. This decline in $\mathrm{NH}_{3}-\mathrm{N}$ was most closely associated with an increase in ADIN in the diet. Satter and Slyter (1974) suggested a minimum rumen $\mathrm{NH}_{3}-\mathrm{N}$ concentration of $5 \mathrm{mg} / 100 \mathrm{ml}$ is required for optimum microbial protein synthesis. However, Qrskov (1982) suggested that $\mathrm{N}$ requirements for optimum microbial growth are less than requirements for maximum organic matter digestion. During the current study, ruminal $\mathrm{NH}_{3}-\mathrm{N}$ remained above the minimum described by Satter and Slyter (1974). Hence, microbial protein synthesis and flow to the small intestine during this portion of the grazing year should not have been limited by $\mathbf{N}$ supply. In contrast, $\mathrm{NH}_{3}-\mathrm{N}$ concentrations in LSept and LOct were below the minimum level $(>20 \mathrm{mg} / 100 \mathrm{ml}$ ) required for maximum digestion ( rskov 1982). If $\phi$ rskov's estimates can be applied to the current situation, data suggest that feeding a small amount of protein supplement in early October might have benefited forage digestion and animal performance.

Ruminal pH (Table 5) ranged from 6.1 to 6.8 during the study. Under grazing conditions, rumen pH normally varies from 6.3 to 7.0 due to the time spent grazing and ruminating in relation to ruminal VFA production (Qrskov 1982). Generally, diurnal variaton in $\mathrm{pH}$ was low across season. Declining diet quality with advancing season was reflected in a general increase in rumen $\mathrm{pH}$ from EAug to LOct. As mentioned earlier, rate and extent of IVOMD declined from EAug to LOct suggesting the rate and quantity of VFA production would also decline. Thus, rumen $\mathbf{p H}$ would be expected to increase with plant maturity, as a smaller quantity of VFA would be buffered by larger amounts of saliva associated with increased chewing time and rumination of dormant forages.

Total concentrations and molar proportions of ruminal VFA

Table 6. Total concentration and molar proportions of ruminal volatile fatty acids in beef steers grazing blue grama rangeland during different sampling periods.

\begin{tabular}{|c|c|c|c|c|c|}
\hline \multirow[b]{2}{*}{ Item } & \multicolumn{4}{|c|}{ Sampling period } & \multirow[b]{2}{*}{$\mathbf{S E}^{1}$} \\
\hline & EAug & LAug & LSept & LOct & \\
\hline Total VFA, mmoles/liter & $96.0 b^{2}$ & $106.3 \mathrm{a}$ & $95.7 \mathrm{~b}$ & $91.5 \mathrm{~b}$ & 2.2 \\
\hline Acetate & $65.0 \mathrm{a}$ & $65.8 \mathrm{a}$ & $69.6 \mathrm{~b}$ & $70.3 b$ & 0.4 \\
\hline Propionate & $18.2 a$ & $18.0 \mathrm{a}$ & $16.7 b$ & $17.1 \mathrm{~b}$ & 0.3 \\
\hline Butyrate & $11.8 \mathrm{a}$ & $10.5 b$ & $10.2 b$ & $8.8 \mathrm{c}$ & 0.3 \\
\hline Minor Acids ${ }^{3}$ & $5.0 \mathrm{a}$ & $5.7 \mathrm{~b}$ & $3.6 \mathrm{c}$ & $3.7 \mathrm{c}$ & 0.1 \\
\hline
\end{tabular}

'Standard error of treatment means, $n=6$.

Means in a row followed by different letters differ $(P<.05)$.

${ }^{3}$ Minor Acids = Isobutyrate + Valerate + Isovalerate. 
were not affected by season $X$ time of day interactions (Table 6 ). No seasonal pattern of total VFA was apparent, but variation in rates of absorption and ruminal passage may have masked any direct influences of diet on total VFA concentrations.

Proportions of individual acids shifted between early and late periods of the growing season. During this time, molar proportions of acetate increased from approximately 65.0 to 70.3 moles/ 100 moles. An increased percentage of acetate is characteristic of plant cell wall fermentation while higher percentage of propionate represents soluble carbohydrate fermentation. Shifts noted in the current study correspond with a $12 \%$ decline in extent and $1.9 \%$ / hour slower rate (McCollum and Galyean 1985) of IVOMD. Previous work has demonstrated similar shifts in molar proportions of VFA between wet and dry and growing versus dormant seasons in grazing ruminants (Topps et al. 1965, Langlands and Sanson 1976, Playne and Kennedy 1976). Without specific information on production rates and total pool size of VFA at different sampling periods, it is impossible to determine the effect of the observed changes in VFA proportions on energy supply to the animal.

Minor VFA (sum of isobutyrate, isovalerate, and valerate; Table 6) also varied with season. Highest $(P<.05)$ levels were observed in LAug followed by EAug. These minor acids are required by many of the cellulolytic species in the rumen ( $Q$ rskov 1982). Our results suggest ruminal proportions of minor acids were highest during rapid forage growth, declining to lowest levels while steers were grazing dormant forage. Playne and Kennedy (1976) reported significant $(P<.05)$ correlations between bolus $\mathrm{N}$ content and molar proportions of isovaleric and valeric acids $(r=.35$ and .52 , respectively). Furthermore, rumen ammonia concentrations were also highly correlated with proportions of these acids. These relationships are logical, because branched chain VFA are products of amino acid deamination. In our study, minor VFA levels and dietary crude protein followed similar seasonal patterns. Also, ruminal $\mathrm{NH}_{3}-\mathrm{N}$ was positively correlated $(P<.01)$ with isobutyrate $(r=.56)$, isovalerate $(r=.84)$ and valerate $(r=.85)$. Microbial growth and degradation of grazed forage could be limited by deficient supplies of $\mathrm{N}\left(\mathrm{NH}_{3}-\mathrm{N}\right)$ and branched chain VFA during forage dormancy. These relationships may partially explain the usually poor response of grazing animals to winter supplements containing high levels of nonprotein $\mathbf{N}$, in comparison with natural protein supplements.

\section{Conclusion}

Alteration of diet composition in LOct allowed the cattle to consume available protein and digestible $O M$ in amounts similar to LSept $(1.7,9.0$ and $1.6,10.0 \mathrm{~g} / \mathrm{kg} \mathrm{BW}$ for LSept and LOct, respectively). However, these consumption levels were 40 to $60 \%$ lower than noted in EAug and LAug. During the year of this study, fall moisture and temperature conditions were conducive to forb production. In other years forbs may not form as large a portion of the diet as noted presently. Our results provide a study of forb influences on dietary nutrients and digestibility and intake of organic matter (McCollum and Galyean 1985).

The value of $\mathrm{CP}$ as a measure of dietary $\mathrm{N}$ status is questionable, especially during periods when forbs contribute substantial portions to the diet. Although availability of $\mathrm{N}$ and extent of IVOMD of forb containing diets may be reduced, it appears that these diets can be consumed in greater amounts (McCollum and Galyean 1985) and thereby allow the grazer to maintain or improve its plane of nutrition during periods of declining grass quality and potential intake.

Finally, results suggest that nutritional stress possibly occurred as early as mid-September. Normally, feed supplements would not be offered until November or December, well into the dormant season. But, changes in the acetate:propionate ratio and rate and extent of IVOMD from LAug to LSept imply that ruminal microflora were degrading the more digestion-resistant fibrous compo- nents in the diet. These changes, coupled with the observed declines in nutrients ( $\mathrm{NH}_{3}-\mathrm{N}$ and branched chain VFA) required by fiberdigesting microbes, could have reduced the efficiency of forage digestion in the rumen. Feeding small amounts of a low bypass, natural protein supplement in the late growing season would supply both $\mathrm{NH}_{3}-\mathrm{N}$ and branched chain VFA. However, the efficacy of such a program, from both an animal performance and financial standpoint, cannot be discerned without further study.

\section{Literature Cited}

AOAC. 1980. Official methods of analysis (13th ed.). Association of Official Analytical Chemists. Washington, D.C.

Broderick, G.A., and J.H. Kang. 1980. Automated simultaneous determinations of ammonia and total amino acids in ruminal fluid and in vitro media. J. Dairy Sci. 33:64-75.

Cook, C.W. 1983. Forbs need proper ecological recognition. Rangelands 5:217-220.

Cordova, F.J. 1978. Intake and nutritive value of forage grazed by cattle on fertilized and unfertilized blue grama rangeland. $P h . D$. Thesis, New Mexico State Univ. Univ. Microfilms. Ann Arbor, Mich. (Diss. Astr. 38:3971).

Goering, H.K., and P.J. Van Soest. 1970. Forage fiber analysis (apparatus, reagents, procedures and some applications). USDA-ARS Handbook No. 379.

Goetsch, A.L., and M.L. Galyean. 1983. Influence of feeding frequency on pasage of fluid and particulate markers in steers fed a concentrate diet. Can. J. Anim. Sci. 63:727-730.

Havstad, K.M. 1977. Effects of range site and nitrogen fertilization upon botanical and chemical content of cattle diets. Unpublished M.S. Thesis. New Mexico State Univ., Las Cruces.

Jung, H.G., and G.C. Fahey, Jr. 1983. Nutritional implications of phenolic monomers and lignin. J. Anim. Sci. 57:206-219.

Kempton, T.J., J.V. Nolan, and R.A. Leng. 1977. Principles for the use of nonprotein nitrogen and bypass protein in diets for ruminants. World Anim. Rev. 22:2-10.

Kothmann, M.M. 1980. Nutrition of livestock grazing on range and pasture lands, p. 56-90. In: D.C. Church (ed.), Digestive physiology and nutrition of ruminants (2nd ed.). $O$ and B Books, Corvallis, Ore.

Langlands, J.P., and J. Sanson. 1976. Factors affecting the nutritive value of the diet and the composition of rumen fluid of grazing sheep and cattle. Aust. J. Agr. Res. 27:691-708.

MeCollum, F.T., and M.L. Galyean. 1985. Cattle grazing blue grama rangeland II. Seasonal forage intake and digesta kinetics. J. Range Manage. 38:543-547.

Mertens, D.R. 1979. Effects of buffers upon fiber digestion, p. 65-80. In: W.H. Hale and P. Meinhardt (eds.), Regulation of acid-base balance. Church and Dwight Company, Inc., Piscataway, N.J.

NRC. 1984. Nutrient requirements of domestic animals. No. 4. Nutrient requirements of beef cattle (6th ed.). Nat. Acad. Sci. Nat. Res. Council. Washington, D.C.

Orskov, E.R. 1982. Protein nutrition in ruminants. Academic Press, New York.

Pfister, J.A., G.B. Donart, R.D. Pieper, J.D. Wallace, and E.E. Parker. 1984. Cattle diets under continuous and four-pasture, one-herd grazing systems in south-central New Mexico. J. Range Manage. 37:50-54.

Pieper, R.D., J.R. Montoya, and V.L. Groce. 1971. Site characteristics on pinyon-juniper and blue grama ranges in south-central New Mexico. New Mexico Agr. Exp. Sta. Bull. 573.

Pieper, R.D., A.B. Nelson, G.S. Smith, E.E. Parker, E.J.A. Boggino, and C.F. Hatch. 1978. Chemical composition and digestibility of important range grass species in south-central New Mexico. New Mexico State Exp. Sta. Bull. 662.

Playne, J.J., and P.M. Kennedy. 1976. Ruminal volatile fatty acids and ammonia in cattle grazing dry tropical pastures. J. Agr. Sci. (Camb.) 86:367-372.

Satter, L.D., and L.L. Slyter. 1974. Effect of ammonia concentrations on rumen microbial protein production in vitro. Brit. J. Nutr. 32:199-208.

Short, H.L., R.M. Blair, and C.A. Segelquist. 1974. Fiber composition and forage digestibility by small ruminants. J. Wildl. Manage. 38:197-309.

Sparks, D.R., and J.C. Malechek. 1968. Estimating percentage dry weight in diets using a microscopic technique. J. Range Manage. 21:264-265.

Tilley, J.M.A., and R.A. Terry. 1963. A two-stage technique for the in vitro digestion of forage crops. J. Brit. Grassl. Soc. 18:104-111. 
Topps, J.H., W.C. Reed, and R.C. Elliott. 1965. The effect of season and of supplementary feeding on the rumen contents of African cattle grazing subtropical herbage II. $\mathrm{pH}$ values and concentrations and proportions of volatile fatty acids. J. Agr. Sci. (Camb.). 64:397-402.
Van Soest, P.J. 1982. Nutritional ecology of the ruminant. O and B Books, Corvallis, Ore.

Waldo, D.R., and H.K. Goering. 1979. Insolubility of protein by four methods. J. Anim. Sci. 49:1560-1568. 